\title{
Effects of Common Vole on Alfalfa Crop
}

\author{
Joanna BABIŃSKA-WERKA
}

\begin{abstract}
Babińska-Werka J., 1979: Effects of common vole on alfalfa crop. Acta theriol., 24, 22: 281-297 [With 4 Tables \& 4 Figs.]

From 1973-1974, that is, during a period of increase in the numbers of rodents and during their mass occurrence, examination was made of the damage done by the common vole Microtus arvalis in a field of alfalfa. The eightfold increase in the voles' density from spring to autumn (1974) was accompanied by a sixfold increase in the amount of damage done to the alfalfa yield during the period from the first to the third mowing. Analysis was made of two processes compensating for loss in alfalfa yield: the process of weed invasion on the crop and the regeneration of alfalfa. A straight-line relation was found between the amount of alfalfa losses and increase in weed biomass. The rapid regenerative process of alfalfa in spring, compensating for the damage done by rodents during the winter, declined as the growing season proceeded. The ratio of destroyed alfalfa to that consumed by voles increased from $1-2$ in spring to 5-9 at the first mowing and to 14 at the third one. A model of the effect of a vole population on an alfalfa crop is presented in this paper.

[Res. Inst. Environ. Develop., Krzywickiego 9, 02-078 Warszawa, Poland].
\end{abstract}

\section{INTRODUCTION}

The common vole Microtus arvalis (P a ll a s, 1779) is one of the pests of cultivated fields. There are, however, no studies defining the amount of damage done by this species of rodent. It is considered that in Poland in years of their mass occurrence voles cause damage to the value of several million zloties (A ndrzeje wski, 1974); but these data are not supported by the corresponding empirical evaluations. Up to the present studies have been concentrated chiefly on evaluation of the biomass consumed by these rodents, estimating it by means of bioenergetic methods. Consumption for the rodent population varied from a fraction of a percentage to over 12 per cent of total primary production of the given biocenosis (R y s zkowski, 1969; Babińska, 1972; Zlot in, 1975).

Far less attention has been devoted to plant matter destroyed, but not eaten, by rodents. Data relating to damage done by voles are only fragmentary, but it would seem that loss in primary production due to 
destruction of plants may be several times greater than loss of plant biomass consumed by voles ( $\mathrm{R}$ u ž i c, 1967; C h od a šova, 1970a; Grodziński et al., 1977).

Voles grazed in the immediate vicinity of their burrows and consequently the majority of losses occur in plants situated near colony i.e. a system of connected burrows with many openings (Formozov \& $\mathrm{K}$ iris 1937a; Bas henina, 1962). Alfalfa is a crop the most prefered by field voles (Bashenina, 1962; Kratochvil, 1959) and therefore in this crop among any others the greatest damage is done.

Destruction of alfalfa on the area occupied by the vole colony triggers two different processes, resulting in partial compensation for losses. One of them is the phenomenon of alfalfa regeneration, as the result of which new shoots grow again on the parts of plants gnawed by voles ( $\mathrm{K} \mathrm{r} \mathrm{a}$ tochvíl, 1962; Spitz, 1967), the second - weed invasion of sites in the crop left bare by the rodents ( $\mathrm{Kratochvíl,} \mathrm{1962;} \mathrm{Ružic,}$ 1967).

The purpose of the present study was to estimate the total loss of alfalfa biomass, i.e., the damage done in this crop by voles, and to compare it with the alfalfa biomass consumed actually by them. The process of alfalfa regeneration and weed invasion in alfalfa crops was also considered.

\section{STUDY AREAS}

The studies were made in five different parts of Poland: in the south in the Nysa district $\left(50^{\circ} 28^{\prime} \mathrm{N} ; 17^{\circ} 20^{\prime} \mathrm{E}\right)$, Brzeg district $\left(50^{\circ} 52^{\prime} \mathrm{N} ; 17^{\circ} 30^{\prime} \mathrm{E}\right)$ and in the north in the Bydgoszcz district $\left(53^{\circ} 10^{\prime} \mathrm{N} ; 18^{\circ} 0^{\prime} \mathrm{E}\right)$ and Mogilno $\left(52^{\circ} 38^{\prime} \mathrm{N} ; 17^{\circ} 50^{\prime}\right)$, and also at Łomna on the experimental field of the Institute of Ecology, Polish Academy of Sciences $\left(52^{\circ} 25^{\prime} \mathrm{N} ; 20^{\circ} 50^{\prime} \mathrm{E}\right)$.

The research was made during 2 years, beginning in the spring of 1973 and ending in the autumn of 1974. During this period the population was increasing in abundance, which led, in autumn of 1974 to a mass occurrence of voles, up to a density of more than 1,000 individuals/ha.

The investigation concerned an Hungarian variety of alfalfa, Medicago sativa, on fields that were 2-4 years old, and cultivated according to standard agrotechnical practices i.e., 3 mowings during a vegetation season, harrowing, and fertilization.

\section{STUDY METHODS AND MATERIAL}

\subsection{Method for Estimating Plant Biomass near Colonies}

In order to define the range of the voles' penetration in search of food in the alfalfa crop examination was made of plant biomass at different distances from the centre of the colony, using the method proposed by $\mathrm{Babinska-Werka}$ (1975). In order to estimate the biomass of the above ground parts of plants samples were taken from an area of $314 \mathrm{~cm}^{2}$ marked out by a metal hoop. In 
early spring and autumn, i.e. when plants were still low, they were cut off at ground level. In spring the evaluation concerns the effect of voles winter feeding on the alfalfa during the initial phases of its growth, and in autumn it concerns the degree of reduction by voles of alfalfa regrowth after the last mowing. Before each mowing plants were cut at two heights from the ground to give 2 layers: 1) the layer forming the yield - plants were cut at the height of $5 \mathrm{~cm}$ from ground level, 2) layer forming the residue after mowing i.e., stubble - the part of plant stalks left was cut at actual ground level. In this way the effect of the voles on yield and on its total biomass was estimated before mowing.

Samples were distributed concentrically around the centre of the colony within the area it occupied. In order to facilitate appropriate distribution of samples a string net was used to mark places in which samples were taken. The net was laid on the area of the crop occupied by the colony. It was assumed that the biomass of 8 samples lying at a uniform distance from the centre characterized the vegetation of one zone of the colony. Four zones were distinguished within the net which, together with the centre, formed a circle $23 \mathrm{~m}^{2}$ in area. Control samples were taken at random from places not occupied by colonies (taking 33 samples on the given field). Plant biomass was estimated in 4 or 5 colonies chosen at random in the given field for each period and study area.

Each sample was divided into 3 groups of plants: alfalfa, other dicotyledons and monocotyledons. The different groups of plants were dried at a temperature of $85^{\circ} \mathrm{C}$, then weighed with accuracy to $0.1 \mathrm{~g}$. A total of 2,442 plant samples were taken in all study areas in 74 colonies, and 561 control samples.

\subsection{Methods for Estimating Production of Alfalfa and Its Regenerative Ability}

In order to estimate the regenerative ability of alfalfa comparison was made between the biomass of alfalfa exploited in usual agricultural practice (three successive mowings) and the alfalfa biomass exploited experimentally. The experiment was intended to simulate the effect of grazing activity of rodents.

Experimental mowing was carried out on an area, chosen at random, $4 \mathrm{~m}^{2}$ in size, on which in winter (January) the whole of the alfalfa was cut at ground level. From the beginning to the end of the growing season (April-October) the alfalfa was mown 13 times, regularly every 2 weeks, taking 10 random samples of plants (each from an area of $314 \mathrm{~cm}^{2}$ ). One sample consisted of the upper parts of alfalfa cut at ground level. At the same time plants in the study plot which grew outside the area included in the samples, were also cut at the same height.

In order to define production of alfalfa exploited in usual way, ten random samples of plants were taken on the study field at the beginning of vegetation season and immediately before each successive mowing. In autumn during the last few days of October sampling was carried out in order to estimate the alfalfa regrowth after the last mowing.

Laboratory treatment of the material collected was analogical with that used to estimate alfalfa losses.

\subsection{Method for Estimating Density of Voles in the Alfalfa Crop}

The density of voles was estimated four times a year: in spring, directly at the beginning of vegetation season (April), after each of the successive mowings of 
alfalfa, when only the alfalfa stubble was left on the field, and near the end of the growing season (October). The method proposed by Andrzejewski \& G li w i c z (1969), consisting in flooding the vole colonies in order to drive the animals from their burrows, was used.

\section{RESULTS}

\subsection{Damage done by Voles in the Alfalfa Crop}

The three groups of plants distinguished: alfalfa, other dicotyledons and monocotyledons occur in the colony areas throughout the whole growing season. The biomass of alfalfa yield and stubble was lower in the colonies than outside of them (Fig. 1). This was shown by the statistically significant differences $(p<0.05-$ Student $t$ test) between

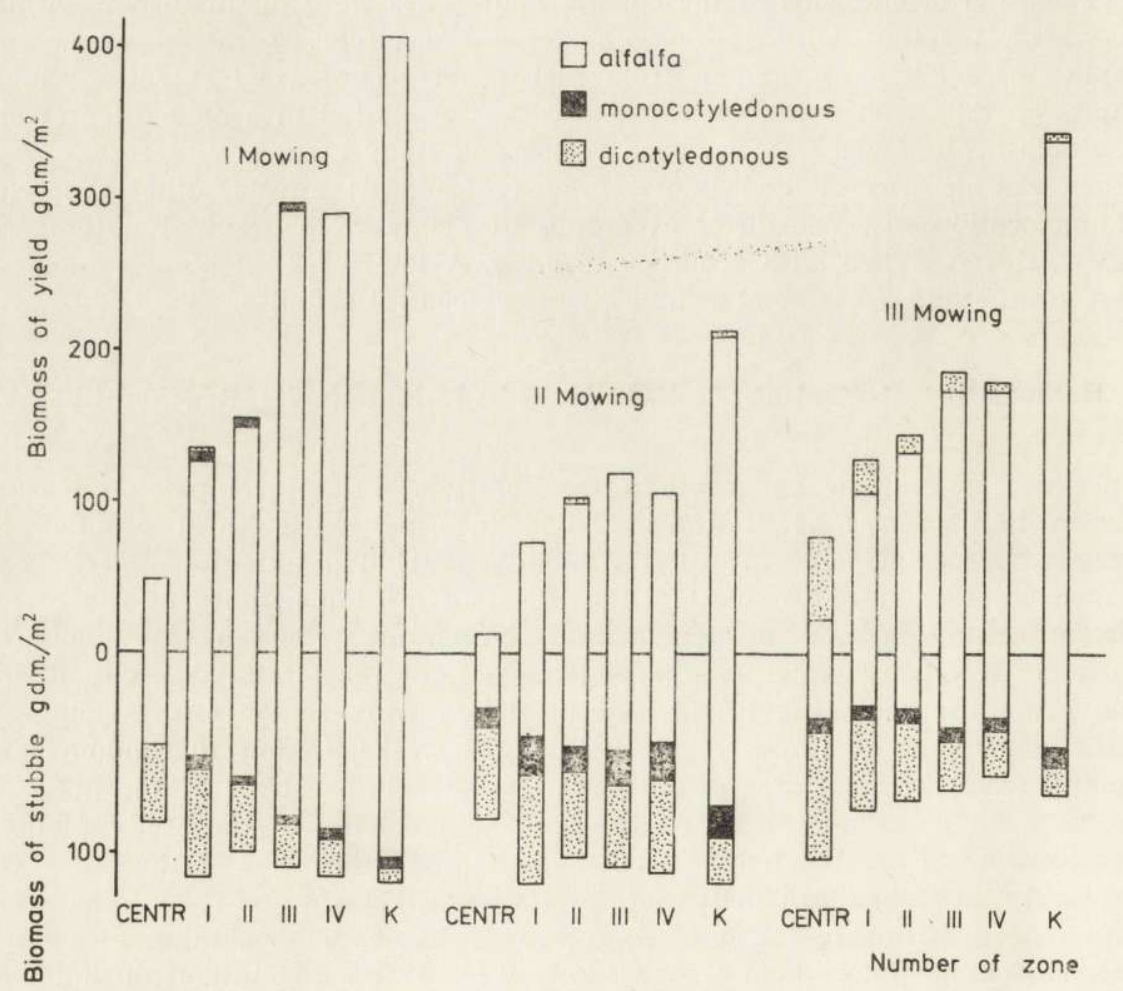

Fig. 1. Mean biomass of yield and stubble in zones of colony and in control (K).

average alfalfa biomass in the control and in the different zones of the colonies (with the exception of the centre of the colony in alfalfa stubble after the third mowing). The voles caused maximum loss of alfalfa in the centre of the colony. Losses of alfalfa decreased with increasing distance from the centre of the colony. 
Examination was next made of the relation between amount of alfalfa biomass in different zones of the colony and distance of these zones from the centre of the colony for the whole growing season. A significant correlation was found between the values examined, with the exception of alfalfa stubble after the second and third mowing. The relation between alfalfa biomass in different zones of the colony and distance of zones from the centre of the colony was a straight-line function (Table 1).

Table 1

Relation between alfalfa biomass in different zones of the colony of burrows and distance of zones from the centre of the colony.

\begin{tabular}{|c|c|c|c|}
\hline Study area & Alfalfa layer & $\begin{array}{l}\text { Equation of } \\
\text { linear } \\
\text { regression }\end{array}$ & $\begin{array}{l}\text { Significance of } \\
\text { coefficient of } \\
\text { correlation } r\end{array}$ \\
\hline \multicolumn{4}{|c|}{ Start of growing season (April) } \\
\hline $\begin{array}{l}\text { Nysa } \\
\text { Nysa } \\
\text { Brzeg } \\
\text { Mogilno } \\
\text { Bydgoszcz }\end{array}$ & $\begin{array}{l}\text { Regrowth of } \\
\text { alfalia } \\
\text { after winter } \\
\text { period }\end{array}$ & $\begin{array}{l}y=0.15+0.23 x \\
y=0.80+0.63 x \\
y=0.01+2.12 x \\
y=0.37+0.21 x \\
y=0.33+0.19 x\end{array}$ & $\begin{aligned} p & <0.01 \\
0.01<p & <0.05 \\
p & <0.001 \\
0.01<p & <0.05 \\
0.001 \leqslant p & <0.01\end{aligned}$ \\
\hline \multicolumn{4}{|c|}{$\underset{1}{\text { Mowing of alfalfa }}$} \\
\hline Nysa & $\begin{array}{l}\text { Yield alfalfa } \\
\text { stubble }\end{array}$ & $\begin{array}{l}y=2.32+2.97 x \\
y=1.78+0.78 x\end{array}$ & $\begin{array}{l}p<0.001 \\
p<0.001\end{array}$ \\
\hline Nysa & $\begin{array}{l}\text { Yield alfalfa } \\
\text { stubble }\end{array}$ & $\begin{array}{l}y=1.88+0.81 x \\
y=1.75+0.14 x\end{array}$ & $\begin{array}{l}p<0.01 \\
\text { NS }\end{array}$ \\
\hline Nysa & $\begin{array}{l}\text { Yield alfalfa } \\
\text { stubble }\end{array}$ & $\begin{array}{l}y=2.31+1.50 x \\
y=1.24+0.07 x\end{array}$ & $\begin{array}{l}p<0.001 \\
\text { NS }\end{array}$ \\
\hline \multicolumn{4}{|c|}{ End of growing season (Ootober) } \\
\hline Nysa & $\begin{array}{l}\text { Regrowth of } \\
\text { alfalfa } \\
\text { after final } \\
\text { mowing }\end{array}$ & $\begin{array}{l}y=0.83+0.25 x \\
y=0.58+0.41 x\end{array}$ & $\begin{array}{r}0.01<p<0.05 \\
p<0.01\end{array}$ \\
\hline
\end{tabular}

$y=$ alfalfa biomass (g dry matter $/ 314 \mathrm{~cm}^{2}$ ).

$x=$ distance from centre of colony $(\mathrm{m})$

In order to estimate the amount of damage done by voles in alfalfa biomass on the field surface occupied by the colony the method suggested by B a bin ska-W e rka (1975) was used. For this purpose the data discussed previously were used: (1) alfalfa biomass in the control areas (2) alfalfa biomass in the centre of the colony, (3) straight-line regression illustrating increase in alfalfa losses with decreasing distance from the 
extreme zones of the colony to its centre. It was assumed that if the voles do not affect plants in the area corresponding to the size of the colony of burrows, then alfalfa biomass can be illustrated in the form of a cylinder, the base of which is formed by the zone of the voles' feeding activity, while the height is the biomass of alfalfa per square unit estimated in control samples (Fig. 2). Alfalfa losses in the colony

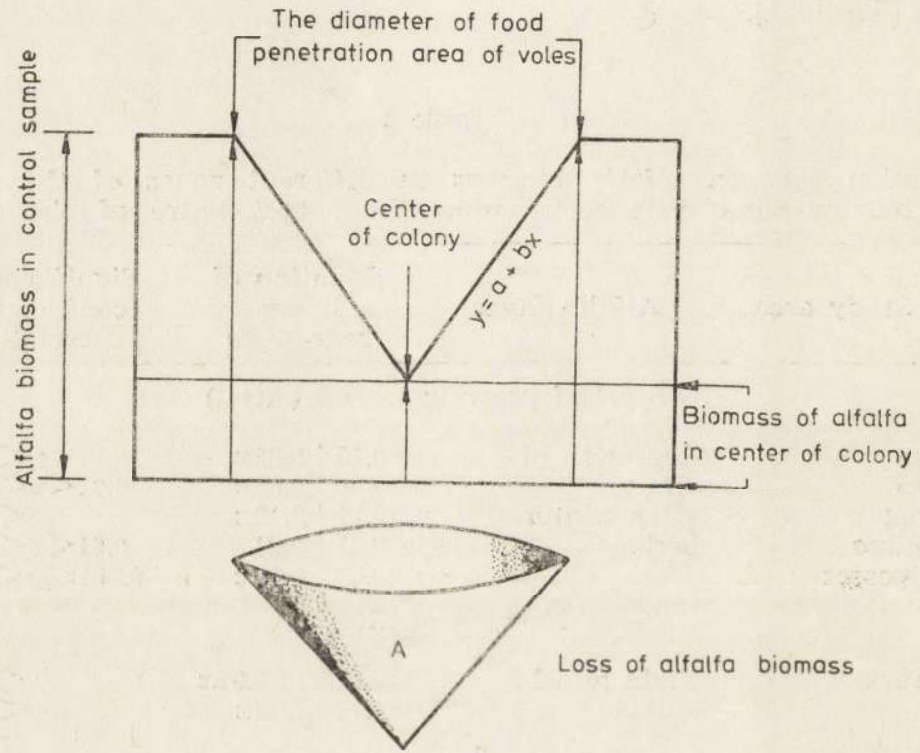

Fig. 2. Plan for evaluating alfalfa losses within the area of the colony of burrows (after B a bińska-Werka, 1975).

can in turn be imagined as the depression forming a kind of hollow in the alfalfa layer in the field. The shape of this depression is similar to a reversed cone, the apex of which lies in the centre of the colony. This cone was obtained by revolving straight line regression round the axis passing through the centre of the colony. The radius of the area of the voles' feeding activity zone was the distance between the centre of the colony and place of intersection of the straight line regression with the height defining biomass in control samples. Knowing the area of the feeding activity zone of the rodents, it was possible to estimate the capacity of the cylinder and cone. From comparison of the two values alfalfa losses in percentages were obtained within the area of the colony of burrows, varying from 20 to $30 \%$. In spring these losses were greater than throughout the rest of the growing season. This might have been due to the long period of the voles' winter feeding and in- 
crease in range of the rodents' feeding activity zone, as is shown by the studies made by B a s he nin a (1962).

An estimate was made of absolute losses in one colony on the basis of percentage losses of alfalfa in one colony and alfalfa biomass per $1 \mathrm{~m}^{2}$ of the crop not exposed to the voles' activity. The percentage values and absolute values of losses in one colony of burrows were calculated per hectare of crop, taking into consideration the average num-

Table 2

Density of rodents, extent of damage done in alfalfa biomass and weed balance in study crops.

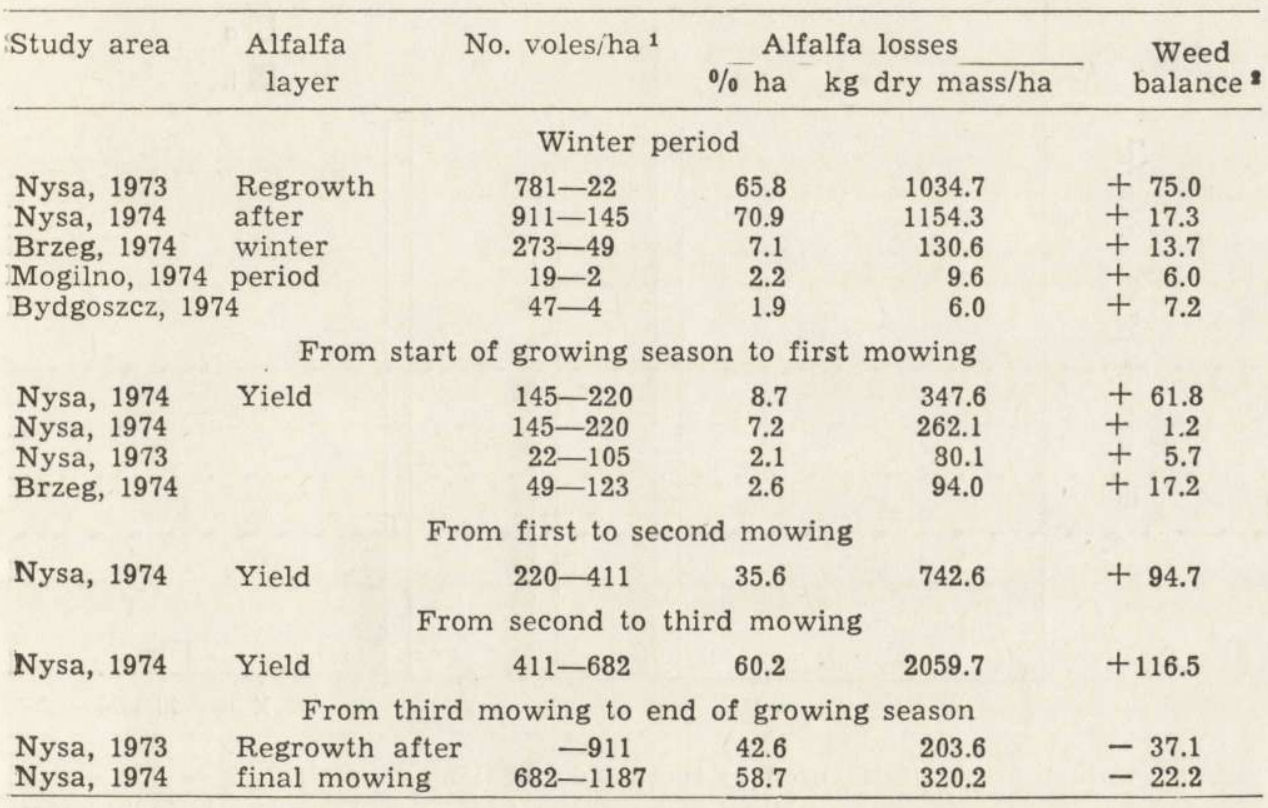

1 After Andrzejewska, 1974; 2 Loss or increase of weed biomass in alfalfa stubble, in $\mathrm{kg}$ dry mass/ha.

ber of colonies per square unit of field. It was found that together with increase in the rodents' density from spring to autumn (145-1187 individuals/ha in 1974) the amount of damage in the alfalfa crop increases from the first mowing $(8.7 \%)$ to the third one $(60.2 \%)$, reaching $58.7 \%$ in October (Table 2).

\subsection{Regeneration of Alfalfa Biomass Losses}

Alfalfa losses caused by voles may be partly reduced by the process of plant regeneration. The regenerative capacity of alfalfa was defined 
by comparing the production of alfalfa biomass exploited in usual agricultural practice and that mown 13 times during the growing season. In the first case yield was similar (about $370 \mathrm{~g}$ dry mass $/ \mathrm{m}^{2}$ ) from both the first and third mowing. The yield of the second mowing was $22 \%$ smaller than the others (Fig. 3).

On the area in which experimental mowing of alfalfa was carried out, in winter (January) the biomass was low - $13 \mathrm{~g}$ dry mass $/ \mathrm{m}^{2}$. Alfalfa biomass obtained from regular mowings was sumed up for successive periods of 6 weeks, which corresponded to the interval between successive normal mowings of this crop.

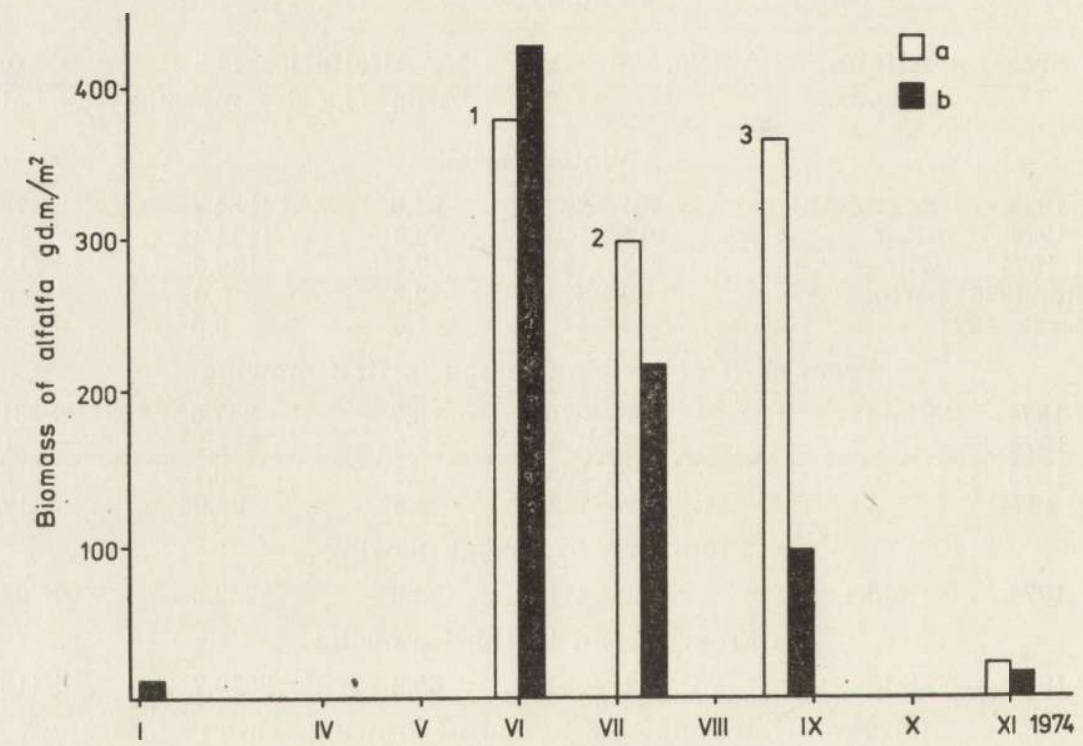

Fig. 3. Production of alfalfa used in the agricultural manner $(1,2,3$ - successive mowings) and used experimentally (mown every two weeks). a - alfalfa biomass at successive mowings, $\mathrm{b}-$ totalled alfalfa biomass mown every 2 weeks.

It was found that as the growing season proceeded there is a continuous decrease from 430 to $20 \mathrm{~g}$ dry mass $/ \mathrm{m}^{2}$ in production of constantly mown alfalfa (Fig. 3). The regenerative ability of alfalfa during the period from spring to the first mowing is considerable, frequent mowing having a stimulating effect on growth of these plants. During this time the biomass of alfalfa mown several times was $11 \%$ greater than the yield from the first mowing. As the growing season proceeds the regenerative ability of alfalfa rapidly declines, the yield from the second mowing was $1 / 3$, and from third mowing 3 times greater, than the biomass of alfalfa mown at short intervals. 
It may be said that during the period from the start of the growing season up to the end of May voles may graze alfalfa without causing serious losses of its biomass. Throughout the rest of the growing season, however, because of the constant decrease in the regenerative ability of this plant, voles cause considerable losses by their feeding.

\subsection{Consumption and Losses Caused by Voles in an Alfalfa Crop}

The estimated average losses $(\mathrm{kg} / \mathrm{ha})$ in alfalfa were calculated per 1 individual $\times$ day of voles'. It was found that the amount of losses caused by one individual during the course of 24 hours depended on

Table 3

Extent of consumption and losses caused by voles in an alfalfa crop.

\begin{tabular}{|c|c|c|c|c|}
\hline \multirow[t]{2}{*}{ Period } & \multirow[t]{2}{*}{ Study area } & \multicolumn{2}{|c|}{$\begin{array}{l}\text { Losses caused by one } \\
\text { individual/ } 24 \text { hours to }\end{array}$} & \multirow{2}{*}{$\begin{array}{l}\text { Ratio of losses } \\
\text { voles consum- } \\
\text { ption }\end{array}$} \\
\hline & & g dry mass & $\mathrm{g}$ green mass & \\
\hline $\begin{array}{l}\text { From end of } \\
\text { growing }\end{array}$ & Nysa & 13.15 & 66 & 2 \\
\hline season to & Nysa & 12.93 & 64 & 2 \\
\hline start of next & Brzeg & 4.74 & 24 & $\overline{1}$ \\
\hline growing season & Mogilno & 5.56 & 28 & 1 \\
\hline From start & Nysa & 57.40 & 287 & 9 \\
\hline of growing & Nysa & 33.20 & 166 & 6 \\
\hline season to & Nysa & 29.53 & 148 & 5 \\
\hline first mowing & Brzeg & 27.60 & 138 & 5 \\
\hline $\begin{array}{l}\text { From first to } \\
\text { second mowing }\end{array}$ & Nysa & 107.10 & 535 & 17 \\
\hline $\begin{array}{l}\text { From second to } \\
\text { third mowing }\end{array}$ & Nysa & 87.74 & 434 & 14 \\
\hline $\begin{array}{l}\text { From third } \\
\text { mowing to } \\
\text { end of growing } \\
\text { season }\end{array}$ & Nysa & 6.99 & 35 & 1 \\
\hline
\end{tabular}

the period for which the rodents grazed. Through the winter up to the spring (April) one vole during a 24 -hour period reduced alfalfa production by $4.74-13.15 \mathrm{~g}$ of dry mass. If we accept, after $\mathrm{Neh} \mathrm{ring}$ (1970), that water content in alfalfa is on an average $80 \%$ during the growing season, the above values fluctuated from 24 to $66 \mathrm{~g}$ of fresh weight (Table 3 ).

Later, during vegetation season the voles even further reduced alfalfa production. From April until the first mowing one vole during a 24-hour period contributed to reduction of from 138 to $287 \mathrm{~g}$ fresh weight of 
lucerne, and $434 \mathrm{~g}$ during the period from the second to third mowing.

The estimated losses of alfalfa included (1) the biomass consumed by the voles, (2) losses caused by destruction of the crop during grazing and, (3) the biomass which could be produced by plants if they had not been damaged earlier by rodents (nonrealized growth). S a w i c k a $\mathrm{K}$ a pusta et. al. (1975) estimated that one vole during a 24-hour period consums about $30 \mathrm{~g}$ of fresh alfalfa. Calculation was made on the basis of these data of the ratio of biomass damaged to the biomass consumed by the rodents (Table 3). During the period from autumn to early spring reduction in alfalfa biomass by voles was either equal to the consumption value, or exceeded it by twice as much. With the passage of the growing season the ratio of damage to consumption increased, so that up to the first mowing alfalfa losses exceeded by 5 to 9 times the biomass consumed by voles, and during the period up to the third mowing this figure had risen to 14 times as much. In autumn the amount of alfalfa losses was equal to the biomass consumed by the voles.

The low ratio of damage to consumption by voles during the winter period might be due to the fact that alfalfa stems were very short during this time and consequently the voles destroyed a smaller amount of plant biomass than during the period before mowings, when alfalfa stems were several times taller than in winter.

One of the causes of increase in ratio of damage to consumption by voles might most certainly have been weakening of the regeneration process of alfalfa losses. As stated previously, there is a decrease in the regenerative ability of alfalfa as the growing season proceeds. Consequently alfalfa stems destroyed by voles did not regrow, resulting in increase in the extent of alfalfa biomass losses.

\subsection{Compensation for Alfalfa Biomass by Monocotyledons and other Dicotyledons Plants}

In the alfalfa crops examined monocotyledons and other dicotyledons occurred on colony areas throughout the whole growing season, in spring in plant regrowth after the winter period, and for the rest of the growing season primarily in alfalfa stubble layer, but only in small quantities in the yield layer (Fig. 1), and in autumn in plant regrowth after the last mowing.

In order to check if alfalfa losses within the colonies were compensated for by weeds, comparison was made by means of the Student $t$ test of the mean combined biomass of all three groups of plants within the different zones of the colony, with the biomass of these plants in control samples. Inadequate compensation for alfalfa losses was not found in 
spring in the majority of crops (Table 4), but for the rest of the growing season alfalfa losses were compensated for by weeds in alfalfa stubble layer and regrowth following the last mowing.

The amounts of weed biomass in the colony and per hectare of crop were estimated in a similar way to that used for alfalfa. It was found

Table 4

Compensation for alfalfa losses by weeds.

Using the Student $t$ test, comparison was made of the combined plant biomass in different zones of the colony and biomass of these plants in the control.

\begin{tabular}{|c|c|c|c|c|c|c|c|}
\hline Period & $\begin{array}{l}\text { Study } \\
\text { area }\end{array}$ & $\begin{array}{l}\text { Plant } \\
\text { layer } \\
\text { examined }\end{array}$ & $\begin{array}{c}\text { Centre } \\
\text { of } \\
\text { colony }\end{array}$ & I & $\begin{array}{l}\text { Zone } \\
\text { II }\end{array}$ & $\begin{array}{l}\text { of colony } \\
\text { III }\end{array}$ & IV \\
\hline Start of & Nysa & Regrowth & 0 & - & - & - & - \\
\hline growing & Nysa & after & - & - & - & - & - \\
\hline season & Brzeg & winter & - & - & - & - & 0 \\
\hline \multirow[t]{2}{*}{ (April) } & Mogilno & period & - & - & 0 & 0 & 0 \\
\hline & Bydgoszcz & & 0 & 0 & 0 & 0 & 0 \\
\hline First & Nysa & Alfalfa & 0 & 0 & 0 & 0 & 0 \\
\hline \multirow{3}{*}{ mowing } & Nysa & stubble & 0 & - & 0 & - & 0 \\
\hline & Nysa & & 0 & 0 & 0 & 0 & 0 \\
\hline & Brzeg & & 0 & 0 & 0 & 0 & 0 \\
\hline $\begin{array}{l}\text { Second } \\
\text { mowing }\end{array}$ & Nysa & & 0 & 0 & 0 & 0 & 0 \\
\hline $\begin{array}{l}\text { Third } \\
\text { mowing }\end{array}$ & Nysa & & + & 0 & 0 & 0 & 0 \\
\hline End of & Nysa & Regrowth & - & 0 & 0 & 0 & 0 \\
\hline $\begin{array}{l}\text { growing } \\
\text { season } \\
\text { (October) }\end{array}$ & Nysa & $\begin{array}{l}\text { of alfalfa } \\
\text { after final } \\
\text { mowing }\end{array}$ & 0 & 0 & - & 0 & 0 \\
\hline
\end{tabular}

0 ; equalizing compensation, difference between biomasses not significant

-; lack of compensation, difference between biomasses significant $(p<0.05)$

+ ; exceeding compensation, difference between biomasses significant $(p<0.05)$.

that additional mono- and dicotyledons biomass was formed as the result of the voles' activity (Table 2). It was only near the end of the growing season in October that voles caused losses among weeds, since during this time, when the density of rodents was great and simultaneously alfalfa biomass was small, the voles were forced to feed on weeds. The formation of additional weed biomass was favoured by the free space within the colony and more fertile soil (rodents' excrement and urine, gnawed alfalfa residue). The greater weed biomass may have been the result of growth of existing weeds or the settlement of new species (K u č er u k, 1963; S pitz, 1968; C hod a šova, 1970b).

Examination was made for the whole growing season to determine whether there is a relation between the amount of alfalfa losses and additional weed biomass in the given crop. A statistically significant 
positive correlation was found between the values examined $(r=0.847$; $p<0.01$ ). The relation between additional weed biomass and loss in alfalfa biomass was a straight-line function $(y=9.48+0.045 x)$. The amount of additional weed biomass increased together with increase in alfalfa losses.

If the extent of alfalfa losses in the crops examined and increase in biomass of weeds are compared, the values do not balance each other. The reason for this is the fact that weeds occurred only in alfalfa stubble throughout the whole growing season and alfalfa provided increase in biomass in this layer. Mono- and dicotyledons could not therefore compensate for alfalfa losses in its total biomass.

\section{DISCUSSION}

The results of the present study indicate that the area within the colony of voles is the place where the voles feed and cause the most damage. Alfalfa losses were not evenly distributed, maximum losses being found in the centre of the colony. This agrees with the studies made by $\mathrm{F}$ ormozov \& $\mathrm{Kir}$ is (1937a) in relation to the common vole, and also F or mozov \& Vor o nov (1939) in relation to Lagurus lagurus $\mathrm{P}$ a $11 \mathrm{a}$ s, 1773.

Variations in plant biomass within vole colonies were analyzed in detail only in a small number of papers. The studies made by $\mathrm{F}$ o $\mathrm{r} \mathrm{m}$ oz ov \& Kiris (1937a) show that with an average colony area of $3 \mathrm{~m}^{2}$, as much as $75 \%$ of the vegetation was destroyed. The real extent of grazing activities might, however, have been far greater, and according to $\mathrm{Kratochvil} \mathrm{(1959)} \mathrm{might} \mathrm{be} \mathrm{as} \mathrm{much} \mathrm{as} \mathrm{over} 50 \mathrm{~m}^{2}$. Zlotin \& C hodašova (1974) estimated the average size of a vole colony as $66 \mathrm{~m}^{2}$, in which losses reached $41 \%$. In the present study the estimate made of damage done by voles during the course of the whole vegetation season revealed increase in alfalfa losses from the first to the third mowing from $8.7 \%$ to $60.2 \%$ (Table 2). Similar data were obtained by Tertil (1976), showing that the greatest losses in yield, of as much as $51.16 \%$ of biomass, were caused by voles at the third mowing. $\mathrm{J} \mathrm{un}$ a t ov (1950) also states that yield losses in meadows were greatest in autumn and reached even as much as $100 \%$. Zlotin \& C hodaš o v (1974), T a h on (1969) explain this by the poorer conditions for plant growth during this time in comparison with the other periods of the growing season.

Alfalfa losses can be reduced by means of the plant's regeneration. It was found that the ability of alfalfa for regeneration declined as the growing season proceeded. It is thus only in spring that alfalfa losses 
can be partly compensated for by regeneration. Confirmation of this is supplied by the low losses of alfalfa at the first mowing (despite considerable winter destruction) and maximum losses in autumn. Spitz (1967) and $\mathrm{T}$ a h o n (1969) found similar properties in respect of meadow plant regeneration. According to these authors, if meadow plants are exposed to voles' activities in the early period of growth, they then possess the ability for regeneration of losses, and consequently the final yield should not be reduced. If, however, voles feed at a later period of the growing season, when the ability of plants for regeneration is low and destruction of even a small number of plants reduces yield to a considerable degree. It is thus not mainly the amount of plant biomass consumed by voles, which determined the amount of plant biomass plants exposed to the rodents' attack is reduced, but the period of time in which grazing took place.

Attention has been drawn in the present paper to the relation between plants consumed and destroyed by voles, taking into account the important effect of the season on the relations examined. Thus when estimating the ratio of amount of alfalfa damage to the biomass consumed by voles, it was found that it increased from $1-2$ in spring and autumn to 14 at the third mowing. Losses did not depend solely on the increasing density of voles during the period from spring to autumn, but also on the cumulating destruction of the alfalfa crop. Zlotin \& C hod a šova (1974), Trojan (1969), R yszkowski et al. (1973) estimated the mean value for the whole growing season of the ratio of damage to the rodents' consumption, and found this was from 1.8 to 3 . Results similar to those obtained in the present study were obtained by $\mathrm{Z}$ lot in (1975), who found that the plant biomass destroyed by rodents was from 6 to 20 times greater than the plant biomass they consumed. In turn Tertil (1976), in 10-day estimates for the period from the second to third mowing of alfalfa, showed that the ratio of damage to consumption was from 4 to 12 .

Reduction in alfalfa losses also takes place owing to weeds compensating for such losses. A straight-line regression has been shown in this paper to exist between the amount of alfalfa losses and additional weed biomass. K r a t o c h víl (1962) found that weed contents in green mass increased from $5.4 \%$ in April to $69.5 \%$ in September. $R$ u ž i c (1967) stated that there may be deterioration in the quality of the yield obtained from the given crop due to the fact that destroyed plants were replaced by weeds. The results given in this paper showed that additional weed biomass could not affect the quality of alfalfa yield, as weeds occurred chiefly in the alfalfa stubble layer. The fact that the alfalfa examined was cultivated in accordance with normal agricultural 
practice might account for this. It would seem that in more weed-infested crops this way of compensating for alfalfa losses might have a. greater influence on the quality of the yield. Nevertheless the fact itself that there were more weeds within the area of the vole colony than in areas not penetrated by rodents may make it impossible for plants previously destroyed by voles to regrow. Confirmation for this assumption is to be found in the study by Formozov \& $\mathrm{Kir}$ is (1937b) on the effect of Microtus socialis Pall. on plants.

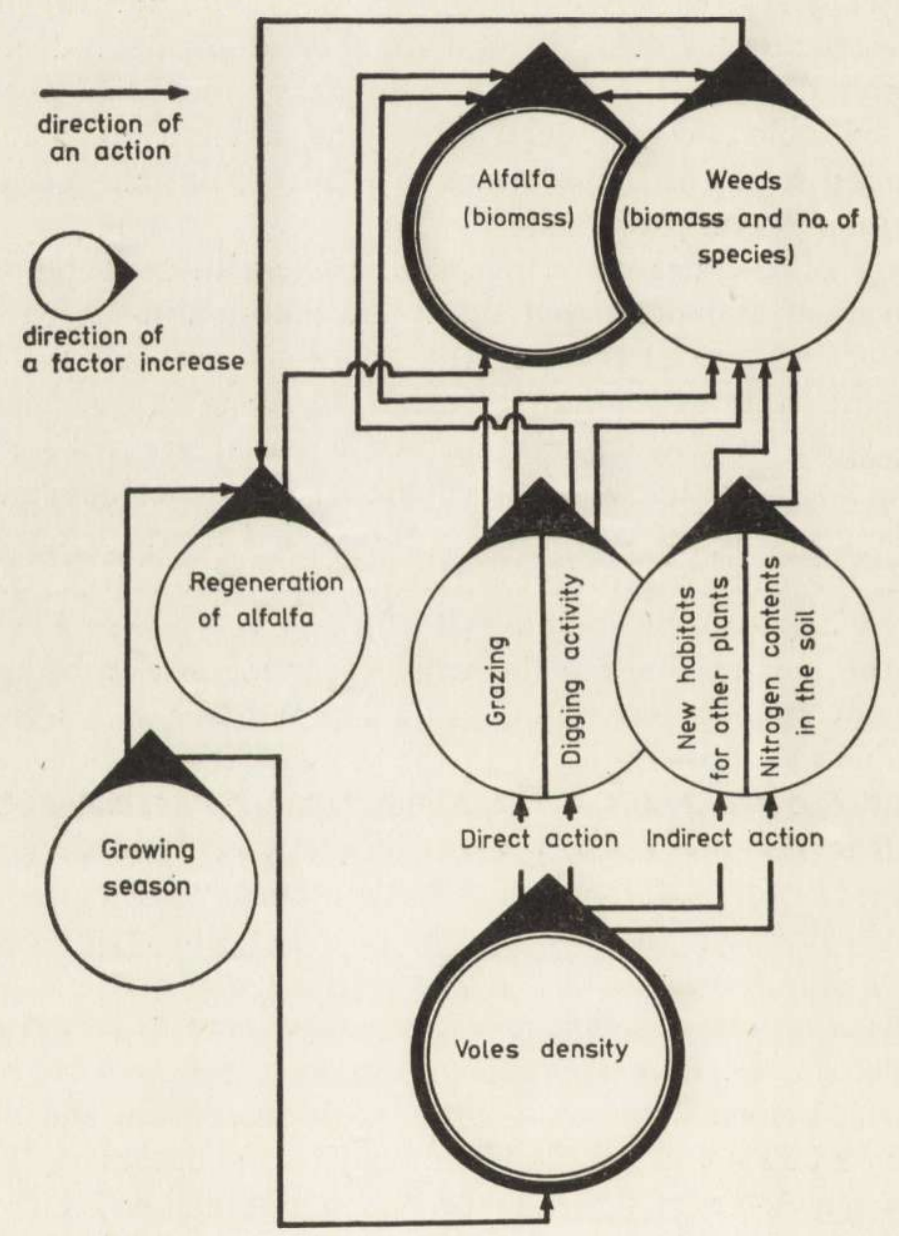

Fig. 4. Ways in which voles affect an alfalfa crop (after B a bińska-Werka, 1978).

It is clear from the study presented here that voles can affect an alfalfa crop in various way (Fig. 4). Increase in the voles' density as 
the growing season proceeds is accompanied by increase in the losses caused by these rodents in alfalfa. Voles caused losses in the alfalfa crop by grazing, digging up the soil, and tunnelling. The reduction in alfalfa production due to grazing includes the biomass actually consumed by the rodents, that destroyed during feeding but not actually consumed, and the biomass not produced owing to stems gnawed by rodents failing to regrow.

Voles also contribute to increase in the biomass and number of weed species in the crop, thus compensating for lucerne losses. Growth of weeds takes place as a result of increase in the amount of nitrogen in the soil (rodents' excrement and urine, bitten-off parts of plants) and also by destroying plants and thus forming a new habitat for other plants. In turn the greater weed biomass in areas penetrated by these rodents may limit regeneration and growth of alfalfa. A second compensatory factor for alfalfa losses caused by voles is the process of its regeneration. Since, however, the regenerative ability of alfalfa decreases as the growing season proceeds, increase in alfalfa biomass as the resuit of its regeneration occurs only during the early part of the growing season.

Acknowledgements: I am greatly indebted to Doc. Dr. R. Andrzejewski, under whose guidance this study was carried out, for his valuable advice and assistance during the course of the work. I must also thank Professor Dr. W. Grodziński, Professor Dr. H. Sandner and Doc. Dr. T. Traczyk for their valued comments on the text.

\section{REFERENCES}

1. Andrzejewski R., 1974: Entomolodzy w walce... z gryzoniami. Życie i Nowoczesność, 238: 3 .

2. Andrzejewski R. \& Gliwicz J., 1969: Standard method of density estimation of Microtus arvalis (Pallas, 1779) for the investigation on its productivity. Small Mammal Newslett., 3: 45-53.

3. B a bińs k a J., 1972: Estimation of rodent in a meadow ecosystem belonging to the community of Molinietalia order. Ekol. pol., 20, 46: 747-761.

4. B a bińska-Werka J., 1975: Metoda szacowania strat wyrządzonych przez nornika rolnego (Microtus arvalis Pall.) na uprawie lucerny. Wiad. ekol., 21, 4: $294-303$.

5. B a bińska-Werka J., 1978: Estimation of losses caused by the field vole (Microtus arvalis (Pallas)) in alfalfa fields. EPPO Bull., 8, 1: 43-46.

6. Bashenina N. V., 1962: Ekologija obyknovennoj polevki i nekotoryje certy ee geografičeskoj izmenčivosti. Izd. Mosk. Univ.: 1-308. Moskva.

7. C hoda šova K. S., 1970a: Formy vozdejstva massovyh zelenojadnyh gryzunov na pervičnuju produkciju travostoja lugovyh stepej. Sredoobrazujušcaja dejatel'nost' životnyh. Izd. Mosk. Univ.: 57-59. Moskva.

8. Chodašova K. S., 1970b: Vlijanie masovyh zelenojadnyh gryzunov na mineralizaciju rastitel'novo opada lugovyh stepej. Sredoobrazujušcaja dejatel'nost' životnyh. Izd. Mosk. Univ.: 60-62. Moskva. 
9. Formozov A. N. \& Kiris I. B. (Prosvirina), 1937a: Dejatel'nost' gryzunov na pastviščah i senokosah. Nabljudenija nad gryzunami-vrediteljami vygunov i senokosov južnoj Ukrainy. Uट̌. zap. MGU, 13: 39-57.

10. Formozov A. N. \& Kiris I. B. (Prosvirina), 1937b: Dejatel'nost' gryzunov na pastvišcah i senokosah. Vlijanie obščestvennoj polevki (Microtus socialis Pall.) i nekotoryh drugih gryzunov na rastitel'nost kizljarskovo rajona Dagestanskoj SSR. Uč. zap. MGU, 13: 59-79.

11. Formozov A. N. \& Voronov A. G., 1939: Dejatel'nost' gryzunov na pastviščah i senokosnyh ugodjah zapadnovo Kazahstana i ee hozjajstvennoe značenie. Uč. zap. MGU, 20: 3-122.

12. Grodziński W., Makomaska M., Tertil R. \& Weiner J., 1977: Bioenergetics and total impact of vole populations. Oikos, 29, 3: $494-510$.

13. Junatov A. A., 1950: Osnovnye čerty rastitelnovo pokrova Mongol'skoj Narodnoj Respubliki. Tr. Mong. Komisii AN SSSR, 39: 12-19.

14. Kratochvíl J., 1959: Hraboš polni Microtus arvalis. Ceskoslovenské Akademie Věd: $1-355$. Praha.

15. Kučeruk V. V., 1963: Vozdejstvo travojadnyh mlekopitajauščih na produktivnost' travostoja stepi i ih značenie $\mathrm{v}$ obrazovanii organiceskoj časti stepnyh počv. Tr. Mosk. Ob-va Ispyt. Prirody, 10: 157-193.

16. Nehring K., 1970: Futtermittel Tabellenwerk. Berlin, $1-460$.

17. R ǔ i c A., 1967: Study of the effect of rodents (Rodentia) upon perennial artificial meadows. Arhiv. Biol. Nauka, 19, 3-4: 147-167.

18. Ryszkowski L., 1969: Estimates of consumption of rodent populations in different pine forest ecosystems. [In: "Energy flow through small mammal populations«, Eds. K. Petrusewicz, L. Ryszkowski]. Państw. Wyd. Nauk.: 281-289. Warszawa.

19. Ryszkowski L., Goszczyński J. \& Truszkowski J., 1973: Trophic relationships of the common vole in cultivated fields. Acta theriol., 18, 7: $125-165$.

20. Sawicka-Kapusta K., Dobrołęcka M., Drożdż A. \& Tertil R., 1975: Bioenergetic parameters of experimental groups of common voles (Microtus arvalis (Pall. 1779)). Ekol. pol., 23, 2: 347-365.

21. Spitz F., 1967: Etat actuel recherches en France sur le méchanisme et le determinisme des populations de Microtus arvalis. EPPO Publ., A, 41: 96-105.

22. T a hon J., 1969: Non related criteria between food consumption by small mammals and waste caused to vegetation. [In: „Energy flow through small mammal populations«, Eds. K. Petrusewicz, L. Ryszkowski]. Państw. Wyd. Nauk.: 159-165. Warszawa.

23. Tertil R., 1976: Wpływ norników zwyczajnych na plon pszenicy ozimej i lucerny. PhD. theses, Jagiellonian Univ., Msc., 45 pp. Cracov.

24. Trojan P., 1969: Energy flow through a population of Microtus arvalis (Pall.) in an agrocenosis during a period of mass occurrence. [In: "Energy flow through small mammal populations«, Eds. K. Petrusewicz, L. Ryszkowski]. Państw. Wyd. Nauk.: 267-279. Warszawa.

25. Zlotin R. I., \& Chodašova K. D., 1974: Rol' zivotnyh v biologičeskom krugovorote lesostepnyh ekosystem. Izd. Nauka: 1-199. Moskva.

26. Zlotin R. I., 1975: Ocenka vozdejstva životnyh-fitofagov na pervičnuju produkciju lugovo-stepičnovo pastvišča. [In: »Rol' životnyh v funkcionirovanii ekosystem "]! MOIP, Izd. Nauka: 1-22. Moskva.

Accepted, March 10, 1979. 
Joanna BABIŃSKA-WERKA

OCENA STRAT SPOWODOWANYCH PRZEZ NORNIKA ZWYCZAJNEGO W UPRAWIE LUCERNY

\section{Streszczenie}

Dwuletnie badania nad nornikiem zwyczajnym Microtus arvalis ( $\mathrm{P}$ a 11 a s, 1779) prowadzone przez połowę cyklu populacyjnego tj. w fazie narastania liczebności gryzoni i w okresie masowego pojawu, pozwoliły ocenić wielkość szkód wyrządzonych przez ten gatunek $\mathrm{w}$ uprawach lucerny.

Oszacowanie strat przeprowadzono na podstawie oceny wielkości biomasy roślin w obrębie kolonii nor gryzoni (Fig. 2). Stwierdzono, że wraz ze wzrostem zagęszczenia gryzoni od wiosny do jesieni (145-1187 osobników/ha w 1974 r.), wielkość szkód w plonie lucerny wzrastała od pierwszego $(8,7 \%-347,6 \mathrm{~kg}$ s.m./ha) do trzeciego pokosu $(60,2 \%-2059,7 \mathrm{~kg}$ s.m./ha), osiągając w odrostach lucerny po ostatnim pokosie $58,7 \%$ (320,2 kg s.m./ha) (Tabela 2). Ubytki lucerny, spowodowane przez norniki w okresie zimy, zostały zniwelowane przez szybką regenerację lucerny w czasie wiosny. W miare upływu sezonu wegetacyjnego stwierdzono szybki spadek zdolności regeneracyjnych lucerny (Fig. 3). Stosunek biomasy lucerny zniszczonej przez norniki do biomasy przez nie skonsumowanej wzrastał od 1-2 na wiosnę, do 5-9 przy pierwszym i do 14 przy trzecim pokosie. Na jesieni, po trzecim pokosie stosunek ten równy był 1 (Tabela 3). Stwierdzono prostoliniową zależność między wielkością ubytków lucerny a przyrostem biomasy chwastów $(r=0,847$; $y=9,48+0,045 x)$. Dodatkowa biomasa chwastów nie kompensowała jednak ubytków lucerny (Tabela 2). W dyskusji omówiono ogólne zależności istniejące pomiędzy populacją nornika polnego a uprawą lucerny (Fig. 4). 